Pak. j. sci. ind. res. Ser. B: biol. sci. 2019 62B(3) 188-194

\title{
Insect Pests Associated With Ornamental Plants
}

\author{
Mehroz Khana, Abdul Ghani Lanjara, Babar Hussain Changac*, Aslam Bukeroa, Ammara Rajput ${ }^{\mathrm{a}}$, \\ Fida Hussain Magsia, Raheela Shah ${ }^{b}$, Abdul Waheed Solangi ${ }^{a}$ and Asif Hussain Changa \\ ${ }^{a}$ Department of Entomology, Sindh Agriculture University, Tandojam, Sindh, Pakistan \\ ${ }^{b}$ Department of Zoology, University of Sindh, Jamshoro, Sindh, Pakistan. \\ ${ }^{\mathrm{c} S t a t e}$ Key Laboratory of Biology of Plant Diseases and Insect Pests, Institute of Plant Protection, \\ Chinese Academy of Agricultural Science, Beijing, China.
}

(received January 26, 2018; revised March 2, 2018; accepted March 13, 2018)

\begin{abstract}
The experiment was conducted during winter season 2014-15 at Sindh Agriculture University Nursery, Tandojam, Pakistan. Five ornamental plants viz; ixora, chrysanthemum, vine, sunflower and jasmine were kept under observation. Collection was done once a week through in situ and sweep net methods. Data was collected by examining 10 randomly selected plants of each ornamental plant species. The collected specimens were brought in the laboratory and identified at species level. The results indicated that there were 24 insect species found active on the ornamental plant species during study period. However, aphid, shield bug, flower feeder, white ant, whitefly, red spider mite and mealy bug were found the most active on Ixora. Aphids, leaf miner, flower feeder, green grass hopper, midges, earwigs and whitefly were found associated with Chrysanthemum. Similarly, aphid, blister mite, mealy bug, midges, red mite and whitefly were found active on vine ornamental creeper. The insects found active on sunflower were aphids, butterfly, green grass hopper, hairy caterpillar, head borer, leaf hopper, midges, ground beetle, red spider mite and white ants. Jasmine plant harboured red spider mite, whitefly, jasmine bug, leaf hopper, white ant and green grass hopper. Among beneficial insects such as predators, pollinators and parasitoids, the green lacewing, honey bee, hoverfly, Trichogramma, praying mantis, zigzag beetle and Tachinid fly were the active insects on all ornamental plants kept under observation. Aphids were found frequently occurring on most of the ornamental plants.
\end{abstract}

Keywords: biodiversity, predators, pollinators, winter season, insect pests, Pakistan

\section{Introduction}

In developed and developing countries from two decades peoples have changed their life style which also increases in the demand of flower products. Increasing in demand of flowers has increased uses of flowers in different societies like birthday and weddings ceremonies etc. (Somerville and Briscoe, 2001). Similarly, ornamental plants are grown for the aesthetic and beauty of home, gardens and community parks. They improve surroundings of our lives from many aspects (Day, 2015).

According to estimations horticultural crops are reduced annually $10 \%$ by attacking of insect pests before harvesting. However, different controlling measures of crop protection and increasing in yield are invented by many aspects (Oerke, 2006). Insects occupy little more space at all types of environment. Insects affect human goods by many ways; they fed on all types of agricultural crops including medicinal plants, weeds, forest trees, ornamental plants etc. Due to the pests attack, the plant

\footnotetext{
*Author for correspondence; E-mail: babar_chang@yahoo.com
}

productivity, landscape unity and aesthetics have been devastated (Su et al., 2015).

It is susceptible to the attack of several insects from vegetative to reproductive phase that causes considerable damage. There are two types of insect pest such as sucking insect pests and chewing insect pests which degrades the aesthetic value of ornamental plants (Rahman et al., 2013). Aphids are soft bodied small insects having no wings. Aphids are found underside of the leaves wherefrom they suck the cell sap by needle like mouthparts. During their presence on plants they also damage the plant and also transmit disease. Aphids occur on all horticultural plants (Farag and Gesraha, 2007). Aphids are also vectors of viruses especially on cucurbit crops. The extensive loss of cell sap results not only in low vigor but also inhibits plant growth. Moreover, all these sucking insect pests cause a great damage by sucking the plant sap. Insect pests cause $35-40 \%$ crop yield losses and ultimately increase the level of damage up to $60-70 \%$ in optimal conditions (Salim, 1999). Thrips are generally common pests of cotton who damage 
cotton crop at different stages from seedling to plant maturity. Mostly the damage of thrips in cotton is recorded when crop reaches on vegetative stage because of most nutritional quality in tissues. Both stages of thrips (nymph and adults) cause damage by sucking cell sap underside of the leaves (Ananthakrishnan, 2009).

The pest scenario varies from place to place with the variation in the agro-climatic conditions of the locality. Information on pest complex in a specific agroecosystem is very much essential in devising pest management strategies which would not only be economically feasible but also ecologically sound. In this region, many herbaceous and woody ornamental plants are cultivated in parks and gardens, which are either regional or imported from other regions for landscape design purposes. The above mentioned reviews indicated that landscape beautification is a crucial issue. It has been noted that in the parks and forestation areas intensely damaged by the insects, the plant productivity, landscape unity and aesthetics have been devastated. Therefore, the present study is designed to ascertain the insect pests with the aim to record their association with different ornamental plants, their identification and damage in the vicinity of Tandojam.

\section{Materials and Methods}

The experiment was conducted at Sindh Agriculture University (SAU) Nursery Tandojam, Sindh, Pakistan during winter season 2014-15. To determine the insect pests associated with ornamental plants at SAU nursery, five ornamentals plants were selected viz; ixora, chrysanthemum, vine, sunflower and jasmine for observing the population fluctuation of different insects and non-insects. Meanwhile population of specimen of insects and non-insects were recorded in situ method from first week of November to last week of January 2014-15. At each observation 10 leaves, one leaf per plant from 10 randomly selected plants of each ornamental plant species. The selected leaves were examined for insect and non-insect species. The specimens of each specie were also collected. The collected specimens were kept into plastic jars (500 $\mathrm{mL}$ ) and jars were covered with muslin cloths so that air could pass into it. The collected specimens were brought to the laboratory, department of Entomology, Faculty of Crop Protection, Sindh Agriculture University Tandojam for identification. Collected insects were killed with ethyl acetate. The killed insects were spread over the table for identification under the supervision of teacher of Department of Entomology, SAU, Tandojam. The collected specimens were separated out to determine their orders and families.

\section{Results and Discussion}

Biodiversity of insect pests on different ornamental plants. The population of different insects (pests, predators and pollinators) belonging to different orders were recorded in ixora, chrysanthemum, vine, sunflower and jasmine from November to January, 2014-15. The collected insects were belonged to insect orders. i.e. Coleoptera, Diptera, Lepidoptera, Homoptera, Neuroptera, Hymenoptera, Acarina, Dermaptera, Mantodea, Arachnida, Hemiptera, Orthoptera, Thysanoptera and Isoptera. The details of insect's species and their taxonomic status is given in Table 1 and seasonal population abundance of insect species on ornamental plants is presented in Fig 1-5.

Insect pest on ixora plant. The ornamental plant ixora harbours the activities of different insect pests. The data indicated that aphid, shield bug, flower feeder, white ant, whitefly, red spider mite and mealy bug were found during the study period i.e. Nov. 5, 2014 to Jan. 15, 2015. The population of these insect pests varied significantly. Aphid appeared in $3^{\text {rd }}$ week of November and remained on the plant until last week of December. However, maximum activities were recorded in the month of December. Its peak population was recorded as 23.14 per plant in the $3^{\text {rd }}$ week of December. Shield bug was seen active from $2^{\text {nd }}$ week of November to $3^{\text {rd }}$ week of January. However, $1^{\text {st }}$ week of January was found suitable for its maximum activities, the bug appeared on ixora with maximum population as 3.15 bug per plant. The flower feeder beetles were seen active from $1^{\text {st }}$ week of November to last week of January. However, their population was found fluctuating throughout study period. Their population pattern was recorded as in and off for many times on ixora plant. The maximum population of the beetle was recorded as 4.5 beetles per plant in the $1^{\text {st }}$ week of January. During study period a single plant was seen affected with the activities of white ant in $4^{\text {th }}$ week of November. The total population of white ant on the plant was recorded as (48.00). The activities of whitefly were recorded from $1^{\text {st }}$ week of November to $2^{\text {nd }}$ week of January. Two peaks in the population were recorded as (14.16) and (11.45) in $2^{\text {nd }}$ week of November and $3^{\text {rd }}$ 
week of January, respectively. The active period for red spider mite was recorded from $3^{\text {rd }}$ week of November to $1^{\text {st }}$ week of January. However, its peak activity was recorded as (22.13) per plant in the $1^{\text {st }}$ week of December. Mealy bug showed their occurrence from $3^{\text {rd }}$ week of December to last week of January. Its peak population was recorded as (44.46) per plant in the last week of December.

Overall mean population during study period was recorded as $(7.35 \pm 2.23),(0.86 \pm 0.27),(2.10 \pm 0.44)$, (3.69 \pm 3.69$),(4.51 \pm 1.17),(7.85 \pm 2.21)$ and $(9.84 \pm 3.86)$ of aphids, shield bug, flower feeder, white ant, whitefly, red spider mite and mealy bug, respectively and depicted in Fig. 1.

Insect pests on chrysanthemum. The data revealed the population of different insect pests appeared on chrysanthemum ornamental plants. Aphid, flower feeder and whitefly were the same insects, which were also found attacking ixora. The other insect pests found attacking chrysanthemum were leaf miner, green grass hopper, midges and earwigs. The insects were found attacking chrysanthemum from $2^{\text {nd }}$ week of November, 2014 to last week of January, 2015.

The maximum activities of whitefly (23.56), midge (8.00) and leaf miner (9.67) were recorded in the $4^{\text {th }}$ week of November, 2014. Whereas; aphid and earwigs displayed their maximum activities in the $2^{\text {nd }}$ and last week of December, 2014 as (7.00) and (9.00) per plant, respectively. Last week of November 2014 and $1^{\text {st }}$ week of January, 2015 were the most favourable time for the activities of flower feeder.

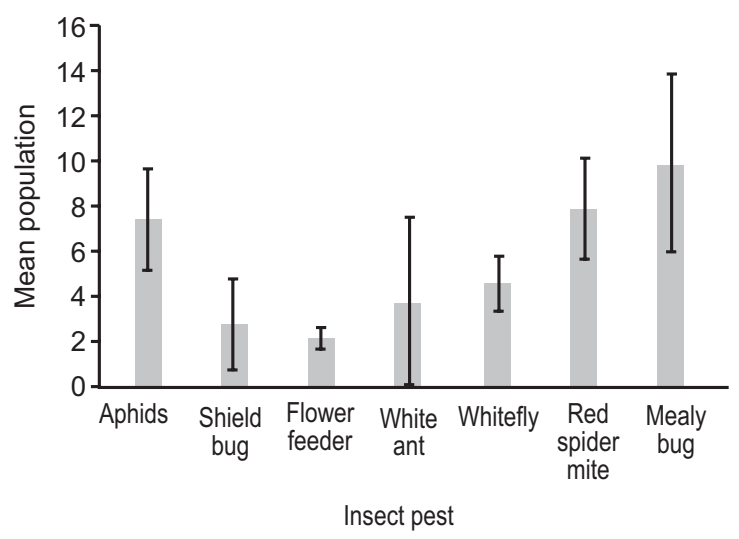

Fig. 1. Overall mean population per plant of insect pests on ixora ornamental plant
Figure 2 showed the overall populations as $(2.91 \pm 0.60)$, (4.12 \pm 0.84$),(3.31 \pm 0.80),(2.55 \pm 0.80),(3.58 \pm 0.86)$, $(3.73 \pm 0.70)$ and $(7.65 \pm 1.97)$ per plant for aphids, leaf miner, flower feeder, green grass hopper, midges, earwigs and whitefly, respectively.

Insect pests on vine. Vine ornamental creeper harboured aphids, blister mite, mealy bug, midges, red spider mite and whitefly. All these insects showed their occurrence of vine crop from $1^{\text {st }}$ week of November to last week of January 2015, except whitefly who started its activities on week later to other insect pests. The maximum per plant population of these insects were recorded as (aphid 4.32 in the $2^{\text {nd }}$ week of November, 2014), (blister mite 3.70 in the $3^{\text {rd }}$ week of January, 2015), (mealy bugs 7.45 in the last week of December, 2014), (midges 3.19 in the last week of December, 2014), (red mite 3.32 in the last week of November, 2014) and (whitefly 8.32 in the $3^{\text {rd }}$ week of November, 2014).

Figure 3 showed the overall mean populations per plant of aphid, blister mite, mealy bug, midges, red mite and whitefly, which indicated that all these insects were non-significantly appeared on vine creeper. The overall population of these insects range as $(2.29 \pm 0.51$ to $2.02 \pm 0.32$ ) per plant.

Insect pests on sunflower. The ornamental plant sunflower harboured different insect pests. The data indicated that aphid, butterfly, green grass hopper, hairy caterpillar, head borer, plant hopper, midges, ground beetle, red spider mite and white ants were found during study period i.e., Nov. 5, 2014 to Jan. 15, 2015. The population of these insect pests varied significantly.

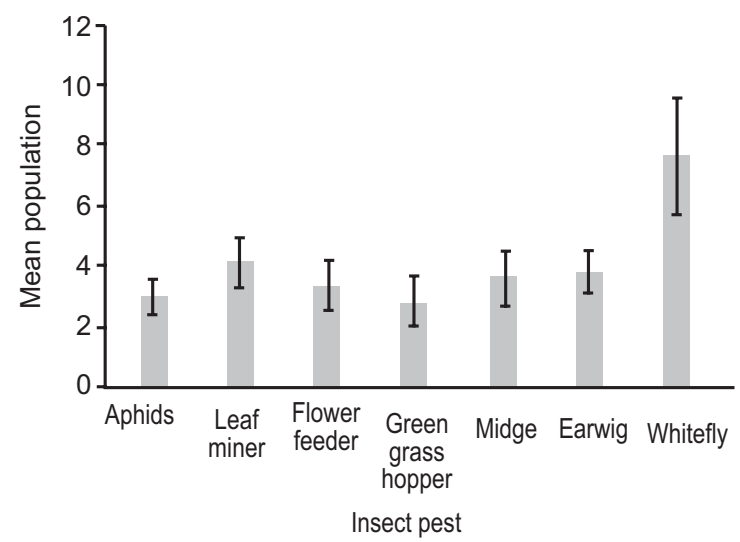

Fig. 2. Overall mean population per plant of insect pests on chrysanthemum ornamental plant 
Aphid appeared in $1^{\text {st }}$ week of November and remained on the plant until last week of January. However, maximum activities were recorded in the month of November. Its peak population was recorded as 3.45 per plant in the $4^{\text {th }}$ week of November. Butterfly was seen active from $1^{\text {st }}$ week of November to the last week of January. However, the last week of January was found suitable for its maximum activities; the butterfly appeared on sunflower with maximum population as 6.20 per plant. Green grass hopper was seen active from 1st week of November to last week of January. However, their population was found fluctuating throughout study period. The maximum population of green grass hopper was recorded as 6.67 per plant in the last week of November. The activities of head borer were recorded from $2^{\text {nd }}$ week of November to the last week of January. The peak in the population was recorded as (8.27) in the last week of November. Hairy caterpillar was also found active from $1^{\text {st }}$ week of November to the last week of January with maximum population (8.37) per plant, which appeared in the $2^{\text {nd }}$ week of November. Plant hoppers were found active throughout course of study, however, November was found the most active month for them. The maximum population (4.67) of plant hopper was recorded in $2^{\text {nd }}$ week of November. The midges showed their occurrence from 1st week of November to last week of January. Its peak population was recorded as (7.67) per plant twice in the $3^{\text {rd }}$ week of November and 1st week of December, respectively. Ground beetles were found active throughout course of study, however, maximum activities were recorded from $3^{\text {rd }}$ to last week of December. Maximum number

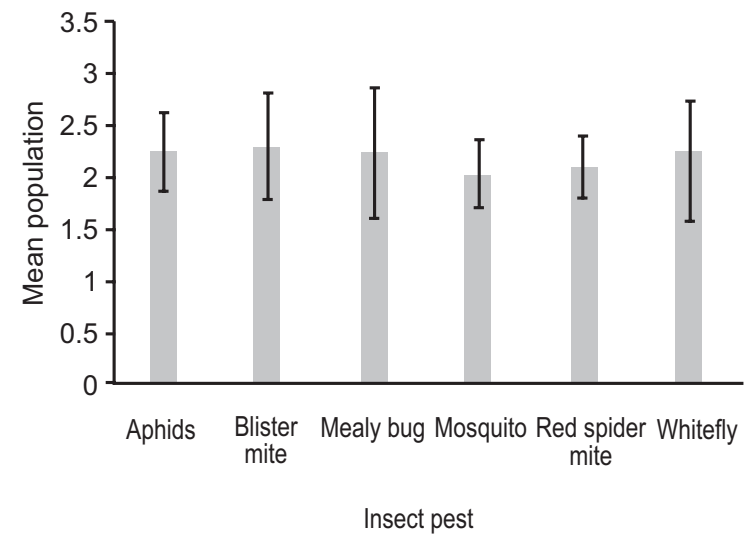

Fig. 3. Overall mean population per plant of insect pests on vine ornamental plant of ground beetle per plant was recorded as (9.00) per plant in the last week of December. The month of November was found active period for red spider mite, However, its peak activity was recorded as (7.32) per plant in the last week of November. During study period, white ants were also found active but their population remained very low, which did not go beyond 5.23 per plant throughout study period.

Figure 4 showed the overall mean populations of different insect pests on sunflower ornamental plant for study period, which were recorded as $(2.57 \pm 0.60)$, (2.32 \pm 0.48$),(4.44 \pm 0.59),(3.95 \pm 0.63),(5.01 \pm .58)$, $(2.80 \pm 0.45),(3.88 \pm 0.79),(3.25 \pm 0.79),(3.30 \pm 0.75)$, (3.25 \pm 0.72$),(3.30 \pm 0.75)$ and $(1.98 \pm 0.62)$ of aphids, butterfly, green grass hopper, hairy caterpillar, head borer, plant hopper, midges, ground beetle, red spider mite and white ants, respectively.

Insect pests on jasmine. The insect pests association and their populations are given as: red spider mite was found the most active pest followed by whitefly, jasmine bug, leaf hopper, white ant, green grass hopper. The maximum populations of white ant (14.00), red spider mite (17.00) and whitefly (21.00) per plant were recorded in the $1^{\text {st }}$ week of January. Green grass hopper and jasmine bug were the most abundant in the $3^{\text {rd }}$ week of November. Their populations were recorded as (7.34) and (9.00), respectively. Leaf hopper displayed its maximum population (8.00) in the last week of November.

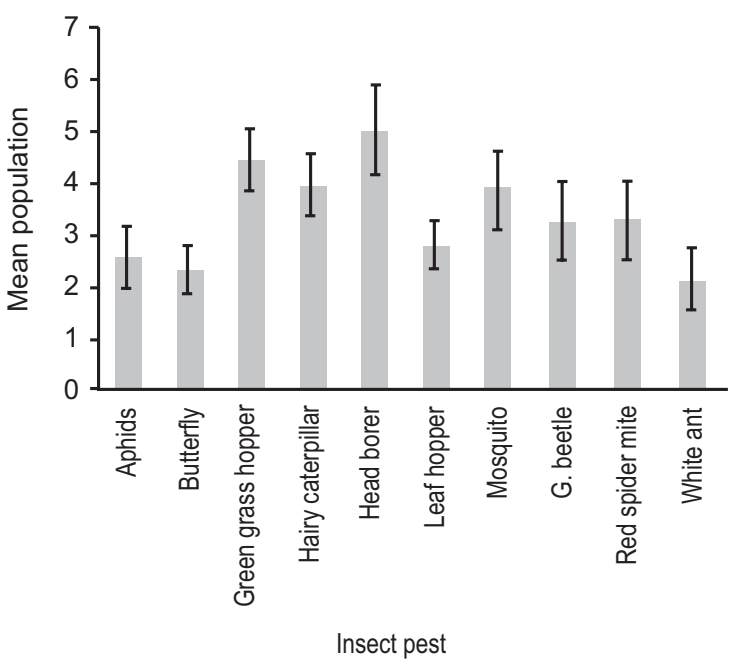

Fig. 4. Overall mean population per plant of insect pests on sunflower ornamental plant 
The overall population of all insect pests appeared on jasmine ornamental plant was recorded as $(5.21 \pm 1.00)$, (3.61 \pm 1.55$),(3.53 \pm 1.00),(3.38 \pm 0.83),(3.00 \pm 1.22)$ and $1.84 \pm 0.54)$ of red spider mite, whitefly, jasmine bug, leaf hopper, white ant and green grass hopper, respectively. Significant difference $(\mathrm{P}<0.01)$ was also recorded in the population of insect pests appeared on jasmine ornamental plants (Fig. 5).

\section{Predators, pollinator, parasitoids on ornamental}

plants. Beside activities of insect pests, the activities of predators, pollinator and parasitoids were also recorded on the ornamental plants selected for studies. The honey bees were the insects, whose activities were solely recorded as pollinator; whereas, adults of Trichogramma, hoverfly, trichinid fly, green lace wing were also found evolved in pollination of these ornamental plants.

The immature stages of hoverfly, trichinid fly, green lace were found active predators; whereas praying mantis and zigzag beetles were found praying on insect pests of ornamental plants in their adult and immature stage as well. The immature stage of Trichogramma was found active egg parasitoid on lepidopteran insects. Figure 6 showed the overall mean populations of different predators, pollinator, parasitoids on ornamental plants for study period, which were recorded as (0.98 \pm 0.25$),(2.77 \pm 0.69),(3.77 \pm 0.96),(0.88 \pm 0.25)$, $(4.13 \pm .98),(5.66 \pm 1.13)$ and $(4.21 \pm 0.59)$ of green lacewing, honey bee, hover fly, Trichogramma, praying mantis, zigzag beetle and Tachinid fly, respectively.

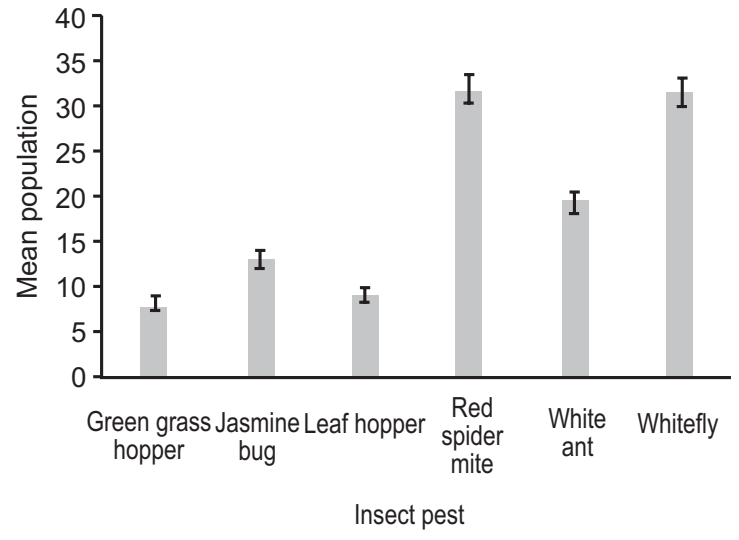

Fig. 5. Overall mean population per plant of insect pests on jasmine ornamental plant
The abiotic factors such as average temperature range from 19.00 to $26.5^{\circ} \mathrm{C}$ and relative humidity percentage 45.00 to 65.00 were conductive for the multiplication of availability of richness of species in the linseed diversity. The details of meteorological record are given in Table. 1.

Though the true dimensions of species biodiversity remain uncertain, estimates ranges from 2.6-7.8 million species with a mean of 5.5 million (Stork et al., 2015). This estimation represents that $20 \%$ of all species on earth and out of them 20,000 new species of all organisms being described each year, most species likely will remain undescribed for many years unless species descriptions increase in rate. About 850,000 $1,000,000$ of all described species are insects. Of the 24 orders of insects, four dominate in terms of numbers of described species, with at least 3 million species included in Coleoptera, Diptera, Hymenoptera and Lepidoptera. The population of different insects (pests, predators and pollinators) belonging to different orders were recorded in ixora, chrysanthemum, vine, sunflower and jasmine from November to January, 2014-15. The collected insects were bellowing to orders Coleoptera, Diptera, Lepidoptera, Homoptera, Neuroptera, Hymenoptera, Acarina, Dermaptera, Mantodea, Arachnida, Hemiptera, Orthoptera, Thysanoptera and Isoptera. The population abundance of insect pests was collected from Ixora flowers. During course of study total numbers of collected insect pests were 3628 out

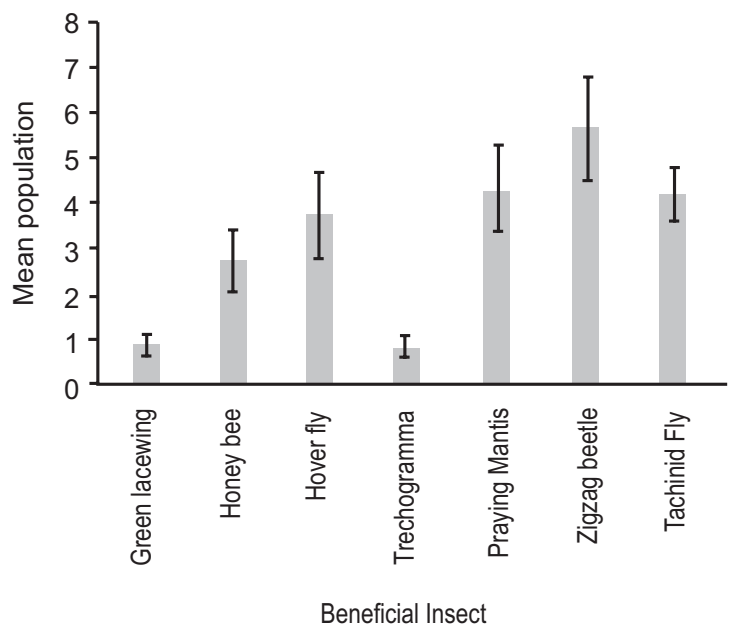

Fig. 6. Overall mean population per plant of predators, pollinator, parasitoids on jasmine ornamental plant 
Table 1. Taxonomy of insect pests in ornamental plants

\begin{tabular}{|c|c|c|c|c|}
\hline Common names & Technical names & Order & Family & Status \\
\hline Aphids & Aphis gossypii (Glover) & Hemiptera & Aphididae & Pest \\
\hline Blister mite & Colomerus vitis (Page) & Acari & Eriophyidae & Pest \\
\hline Danaus Butterfly & Danaus plexippus & Lepidoptera & Danaidae & Pest \\
\hline Flower feeder & Helicoverpa armiger (Hubner) & Lepidoptera & Papilionidae & Pest \\
\hline Flower thrips & Thrips orientalis (Bagnall) & Thysanoptera & Thripidae & Pest \\
\hline Green grass hopper & Atractomorpha acutipennis (Gue) & Orthoptera & Acrididae & Pest \\
\hline Green lacewing & Chrysoperla carnea (Stephens) & Neuroptera & Chrysopidae & Predator \\
\hline Hairy caterpillar & Spilosoma obliqua (Walker) & Lepidoptera & Arctiidae & Pest \\
\hline Head borer & Helicoverpa armigera (Hubner) & Lepidoptera & Noctuidae & Pest \\
\hline Honey bee & Apis florae (Fab) & Hymenoptera & Apidae & Pollinator \\
\hline Housefly & Musca domestica (Linn) & Diptera & Muscidae & Pest \\
\hline Hover fly & Eristalis sp. (Lat) & Diptera & Syrphidae & Predator \\
\hline Jasmine bug & Antestia cruciata (Fabricius) & Hemiptera & Pentatomidae & Pest \\
\hline Leaf hopper & Amrasca biguttula (Ishida) & Hemiptera & Cicadellidae & Pest \\
\hline Mealy bug & Phyllococcus oahuensis (Eh) & Hemiptera & Pseudococcidae & Pest \\
\hline Moths & Cochylis hospes (Wal) & Lepidoptera & Tortricidae & Pest \\
\hline Praying Mantis & Sphodromantis viridis (Bur) & Mantodea & Mantidae & Predator \\
\hline Red spider mite & Tetranychus urtecae (Koch) & Acarina & Tetranychidae & Pest \\
\hline Tachinid Fly & Tachina fera (Bigot) & Diptera & Tachinidae & Parasitoid \\
\hline Thrips & Thrips tabaci & Thysanoptera & Thripidae & Pest \\
\hline Trichooramma & Trichorramma minutum (Ril) & Hymenoptera & Trichogrammatidae & Pargcite \\
\hline White ant & Coptotermes formosanus (Shir) & Isoptera & Termitidae & Pest \\
\hline Whitefly & Dialeurodes kirkaldyi (Kotinsky) & Hemiptera & Aleyrodidae & Pest \\
\hline Zigzag beetle & Menochilus sexmaculatus (Fab) & Coleoptera & Coccinellidae & Predator \\
\hline
\end{tabular}

of which 2650 were insect pests and 978 were predators and pollinators. From chrysanthemum plants total numbers of collected insect pests were 3019 out of which 1823 were insect pests and 1196 were predators and pollinators. Furthermore, these results were compared with Lanjar et al. (2014) who reported that during experiment 2991 specimens belonging to 30 species, were collected from mustared alone crop. From 30 species 21 species were pest and 4 were predators and 5 species were pollinators. From mix cropping of mustared and sunflower 3844 specimens belonging to 32 species were collected out of which 23 species were recognized as insect pest while 4 species were predators and 5 species were pollinators. In biodiversity pollinators are globally key mechanism for pollinating the broad spectrum of the plants (Potts et al., 2010).

\section{Conclusion}

There are 24 different species of insects and non-insects were active in winter season. Aphid was found active almost in all ornamental plants studies. November, December and January are favourable months for insect activities. Predators were also found synchronised with insect pests activities.

\section{Acknowledgments}

We are grateful to anonymous reviewers for their constructive comments on earlier draft of this manuscript. We also thank to Prof. Zehua Zhang (Institute of Plant Protection, Chinese Academy of Agricultural Science, Beijing, China) and Prof. Mark Richard McNeill (AgResearch Lincoln Research Centre Christchurch, New Zealand) for their invaluable suggestions on manuscript organization and linguistic revision.

Conflict of Interest. The authors declare no conflict of interest

\section{References}

Ananthakrishnan, T.N., Jesudasan, A.R.W. 2009. Invasive insects in agriculture, medicine and forestry. Current Science, 97: 300-301.

Day, E.R. 2015. Insect pests of ornamental plants, slide show, http.//pubs.ext.vt.edu/2909/2909-1414/2909- 
1414.html.downloaddt. 13.9.2015.

Farag, N.A., Gesraha, M. A. 2007. Impact of four insecticides on the parasitoid wasp, Diaertiella rapae and its host aphid, Brevicoryne brassicae under laboratory conditions. Research Journal of Agricultural and Biological Science, 3: 529-533.

Lanjar, A.G., Solangi, A.W., Khuhro, S.A., Jiskani, R. H., Bukero, A., Rais, M.N. 2014. Effect of mix cropping of mustard and sunflower on insect diversity. Science International, Lahore, 26: 16011606.

Oerke, E.C. 2006. Crop losses to pests. The Journal of Agricultural Science, 144: 31-43.

Potts, S.G., Biesmeijer, J.C., Kremen, C., Neumann, P. Schweiger, O., Kunin, W.E. 2010. Global pollinator declines: trends, impacts and drivers. Trends in Ecology of Evolution, 25: 345-353.

Rahman, M.M., Uddin, M.M., Shahjahan, M. 2013.
Management of okra shoot and fruit borer, Earias vitella using chemical and botanical insecticides for different okra varieties. International of Research Journal of Applied Life Science IRJALS, 2: 1-9.

Salim, M. 1999. Diversity: role in integrated pest management. Science Technical Development, 18: 26-31.

Somerville, C., Briscoe, J. 2001. Genetic engineering and water. Journal of Science, 292: 2217-2217.

Stork, N.E., McBroom, J., Gely, C., Hamilton, J. 2015. New approaches narrow global species estimates for beetles, insects, and terrestrial arthropods. Proceeding of the National Academey of Science, 112: 7519-7523.

Su, Z., Xiaoma, L., Weiqi, Z., Ouyang, Z. 2015. Effect of landscape pattern on insect species density within urban green spaces in Beijing, China. PLOS. Journal, 10: 0119276. 